\title{
Ethano-Botanical and Medicinal Uses of Moringa spp. and Carica spp.
}

\author{
Nishu*, Babaloo Kumar and Chandrawati Jee \\ Department of Biotechnology, A.N College, Patna - 800013, India \\ *Corresponding author
}

\section{A B S T R A C T}

Moringa and Papaya are two most popular medicinal plants of Indo-Gangatic planes which are extensively used for their nutritional and medicinal values. Systematic and scientific investigation were carried out to assess the nutritional and medicinal value of these popular plants variety found in Patna and Munger district of Bihar state. Carica papaya Linn. is an unbranched, perennial, unisexual, dioecious, herb, 3-6 meter tall, with crown at the end of trunk. Leaves: long-petioled, palmately - lobed; lobes: again lobed once or twice, with petiole base and milky latex. Male flowers: $2.5-3 \mathrm{~cm}$ across white, in axillary panicles of chyme. Corolla of male: gamopetalous. Stamens: $5+5$ diplostemonous. Female flower: unisexual, pistillate, actinomorphic, pale-white, with milky latex in solitary or short axillary chymes. Ovaries: 5-carpellary and unilocular, superior; style: short; stigma: 5lobed. Berry: Cylindrical, ovoid or pyriform, with small seeds. Seeds: black, with an outer sappy and an inner hard testa. Latex is anthelminthic, laxative, digestive, febrifuge and used as tonic. It is also applied externally is ring worm, leprosy and other cutaneous infections. The fresh crushed seeds yield the agly cone of glucotropaeolin benzyl isothiocyante which is a bacteriostatic, bacteriocidal \& fungicidal. It is easy to grow is many ecological zone so it can help in achieving the food \& nutrition securities. Similarly Moringa is highly nutritive and medicinal plant found in Indo-Gangatic plane. Moringa oleifera is the most widely cultivated species of the genus Moringa, which is the only genus in the family Moringaceae. It is a fast-growing, drought-resistant tree, native to the southern foothills of the Himalayas in northwestern India, and widely cultivated in tropical and subtropical areas where its young seed pods and leaves are used as vegetables. It can also be used for water purification and hand washing, and is sometimes used in herbal medicine. The result reveals that the both the plant studied are highly nutritive and contains phytochemicals having strong antibacterial Properties.

\section{Introduction}

India is a country of villages where $80 \%$ people used to live in remote villages. India is also blessed with an enormous diversity of plants for harnessing good health for all. Today, in countries like ours, it is not enough to attain food security. The need of the time is to get nutritional security to the hungry millions of people all over the world. In human nutrition, fruits play an important role for the cause of balanced diet. They provide not only energy with foods but also vital protective nutrients like vitamins and minerals. Comparatively fruits are considered as the cheapest sources of natural nutritive foods which help in building resistance against various ailments. Apart from normal uses many fruits have useful medicinal values for curing chronic diseases. Carica papaya 
was first described by Spanish Chronicler Oviedo in 1526 from the Caribbean coast of panama and Colombia. The fruit of Carica papaya is the rich source of vital protective nutrients like vitamins A, B, C, \& Several minerals. Comparatively fruits are considered as the cheapest source of natural nutritive food which help in building resistance against various chronic diseases. Carotenoid content of papaya measures $13.8 \mathrm{mg} / 100 \mathrm{gm}$ of pulp and known as cryptoxanthin. Papain and chrsymopapain are also present in the latex of papaya.

M. oleifera has been used as a traditional medicinal source. Additionally, besides being edible, all the parts of the Moringa tree (e.g., pods, seeds, and leaves) have long been employed for the treatment of many diseases, and therefore, it was called a "miracle vegetable". Since it is a significant source of fats, proteins, beta-carotene, vitamin $\mathrm{C}$, iron, potassium, and other nutrients, the Moringa tree is highly nutritious. For these reasons, some parts of this plant have drawn much attention and have been studied for its various biological activities, including antiatherosclerotic, immune-boosting, anticardiovascular diseases, antiviral, antioxidant, antimicrobial, anti-inflammatory properties and tumor-suppressive effects in skin papillomagenesis, hepatocarcinoma cancer, colon cancer, and myeloma.

\section{Materials and Methods}

Fruits of Papaya and Moringa were collected from six study sites of the district of the Patna and Munger, Bihar. The evaluation and assessment of nutritional and medicinal values were carried out using internationally accepted laboratory techniques. Ripen papaya berry are most commonly eaten fresh merely peeled, cut in wedges and served with a half of lime. Ripe berry of papaya are sliced and crystallized as a sweet meat. Half ripen fruits are made into sauce or is added to ice cream just before freezing. Green berry of papaya is boiled and served as a vegetable. Young leaves are cooked and taken as pot herb. Mature leaves are bitter and must be boiled with a change of water to eliminate much of its bitterness. Leaves contain bitter alkaloid called carpaine and pseudocarpaine which act on our heart and respiration but are destroyed by heat.

\section{Results and Discussion}

The ethno botanical value of the papaya berry and Moringa were evaluated for their use as food and medicine. The results found has been presented in Table 1 .

\section{Food value}

The berry of papaya is regarded as a fair source of iron and calcium; a good source of vitamin A, B and excellent source of vitamin C. Carotenoid content of papaya measures $13.8 \mathrm{mg} / 100 \mathrm{gm}$ of pulp and is named as cryptoxanthin (S.K. Jain, 1968). Liquid portion has been used to reduce enlarged tonsils. In addition, the juice is used for warts, cancers, tumors and skin defects while roots also help to reduce tumors of uterus.

The latex of unripe berry contains two types of proteolytic enzymes called papain and chrsymopapain. The chrsymopapain is most abundant, but papain is twice as potent. Although papain is a protein this enzyme is not damaged by heat. The latex is obtained by making incisions on the surface of unripe berry early in the morning and repeating every 4 to 5 days until the latex ceases to flow. Because of its papain content, a piece of unripe papaya can be rubbed on a portion of tough meat to tenderize it very quickly. Papain has got many other practical applications. It is used to clarify beer, also to treat wool and silk before dyeing, to de-hair 
before tanning and is serves as an adjunct in rubber manufacturing (Singh, V. etal. 2005). It enters into toothpastes, chewing gums, cosmetics and detergents as well as pharmaceutical preparations to aid digestion.

Every part of $M$. oleifera is a storehouse of important nutrients and antinutrients. The leaves of $M$. oleifera are rich in minerals like calcium, potassium, zinc, magnesium, iron and copper. Vitamins like beta-carotene of vitamin A, vitamin B such as folic acid, pyridoxine and nicotinic acid, vitamin $\mathrm{C}, \mathrm{D}$ and E also present in $M$. oleifera. Phytochemicals such as tannins, sterols, terpenoids, flavonoids, saponins, anthraquinones, alkaloids and reducing sugar present along with anti-cancerous agents like glucosinolates, isothiocyanates, glycoside compounds and glycerol-1-9-octadecanoate.

Moringa leaves also have a low calorific value and can be used in the diet of the obese. The pods are fibrous and are valuable to treat digestive problems and thwart colon cancer. A research shows that immature pods contain around $46.78 \%$ fiber and around $20.66 \%$ protein content. Pods have $30 \%$ of amino acid content, the leaves have $44 \%$ and flowers have $31 \%$. The immature pods and flowers showed similar amounts of palmitic, linolenic, linoleic and oleic acids.

\section{Medicinal uses}

The berry of papaya are bitter, acrid, anodyne, stomachic, appetizer, digestive, carminative, anthelmintic, demulcent and diuretic. They are useful in vitiated condition of cough, bronchitis, intestinal worms, ringworm, skin diseases, psoriasis, urinary calculus and injury of the urinary tracts. The latex is anthelmintic, laxative, digestive, febrifuge and tonic. It is applied externally in ringworm, leprosy and other coetaneous affections (Chopra et.al. 1956). The papain extracted from berry of papaya is employed to treat ulcer, dissolve membrane in diphtheria and reduce swelling, fever after surgery. The paste of fresh roots mixed with salt, diluted with water is given to reduce abortion. The decoction of old roots is given to expel round worms. The infusion of dried leaves has been smoked to relieve asthma. It is also taken for stomach troubles and act as purgative and may cause abortion. (S.K. Jain 1968).

Table.1 Comparative value of Papaya and Moringa fruits by chemical analysis

\begin{tabular}{|l|l|l|l|}
\hline \multicolumn{2}{|c|}{ Parameter analysed } & \multicolumn{2}{c|}{ Chemical Values Observed } \\
\hline \multicolumn{2}{|c|}{ Fresh fruit extract } & \multicolumn{1}{c|}{ Papaya } & \multicolumn{1}{c|}{ Moringa } \\
\hline 1 & Nutritional value per $100 \mathrm{~g}$ & $3.4 \mathrm{oz}$ & $3.6 \mathrm{oz}$ \\
\hline 2 & Energy & $179 \mathrm{~kJ}(43 \mathrm{kcal})$ & $64 \mathrm{kcal}(270 \mathrm{~kJ})$ \\
\hline 3 & Carbohydrates & $10.80 \mathrm{~g}$ & $8.25 \mathrm{~g}$ \\
\hline 4 & Dietary fiber & $1.5 \mathrm{~g}$ & $2.0 \mathrm{~g}$ \\
\hline 5 & Fat & $0.24 \mathrm{~g}$ & $1.35 \mathrm{~g}$ \\
\hline 6 & Protein & $0.43 \mathrm{~g}$ & $9.45 \mathrm{~g}$ \\
\hline 7 & Calcium & $(2 \%) 20 \mathrm{mg}$ & $(19 \%) 184 \mathrm{mg}$ \\
\hline 8 & Iron & $(2 \%) 0.22 \mathrm{mg}$ & $(31 \%) 4.02 \mathrm{mg}$ \\
\hline 9 & Magnesium & $(6 \%) 20 \mathrm{mg}$ & $(41 \%) 142 \mathrm{mg}$ \\
\hline 10 & Manganese & $(2 \%) 0.04 \mathrm{mg}$ & $(17 \%) 0.33 \mathrm{mg}$ \\
\hline 11 & Phosphorus & $(1 \%) 10 \mathrm{mg}$ & $(16 \%) 111 \mathrm{mg}$ \\
\hline 12 & Potassium & $(4 \%) 183 \mathrm{mg}$ & $(7 \%) 339 \mathrm{mg}$ \\
\hline 13 & Sodium & $(1 \%) 8 \mathrm{mg}$ & $(1 \%) 9 \mathrm{mg}$ \\
\hline 14 & Zinc & $(1 \%) 0.08 \mathrm{mg}$ & $(6 \%) 0.6 \mathrm{mg}$ \\
\hline 15 & Water & $86 \mathrm{~g}$ & $78.60 \mathrm{~g}$ \\
\hline
\end{tabular}


All parts on Moringa spp. are used for treatment of various diseases under traditional medicinal system in Indian. Its Juice from the leaves is believed to have a stabilizing effect on blood pressure and is used to treat anxiety. It is believed to control glucose levels in cases of diabetes. Mixed with honey and followed by a drink of coconut milk 2 or 3 times a day, leaves are used as a remedy for diarrhea, dysentery and colitis. Leaf juice, sometimes with carrot juice added, is used as a diuretic. Eating leaves is recommended in cases of gonorrhea because of the diuretic action. Leaves and buds are rubbed on the temples for headache. A poultice is made from fresh leaves and applied to reduce glandular swelling. Leaf juice is used as a skin antiseptic. Leaves are used to treat fevers, bronchitis, eye and ear infections, scurvy, and catarrh (inflammation of the mucus membrane). Leaves are considered to be anthelmintic (able to kill intestinal worms). Its leaves are used as a purgative.

\section{Antibiotic Activity}

The extracts of ripe and unripe berry as well as its seeds are very active against Gram +ve bacteria. The substance has protein - like properties. The fresh crushed seeds yield the aglycone of glucotropaeolin benzyl isothiocyante which is bacteriostatic, bacteriocidal and fungicidal (Singh, V. 2005). Papaya skin, pulp and seeds contain a variety of phytochemicals, including carotenoids and polyphenols, as well as benzyl isothiocyanates and benzyl glucosinates, with skin and pulp levels that increase during ripening. Papaya seeds also contain the cyanogenic substance prunasin. Isolated compounds, Kaempferol exhibited the highest activity against all tested microorganisms. Three phenol derivatives, quercetin showed antibacterial activity. Niazinin-A and Stigmasterol also exhibit antibacterial activity. In vitro studies also showed that flavonoids isolated from $M$. oleifera exhibit considerable antimicrobial activity. In our efforts to identify bioactive constituents from medicinal plant of Moringa oleifera, we report in this communication on the antibacterial activities constituents of M.oleifera.

The Methanolic extracts of $M$. oleifera have exhibited a wide range of inhibition zones on all the tested pathogens due to the biologically active biomolecules. These observations may enable to standardize the botanical identity of the drug in crude form and the bioactive compounds in pure form revealed that the antibacterial activity of $\mathrm{M}$. oleifera, methanolic extract are largely due to the presence of phenolic compounds, especially Flavonoids and their synergistic effect of aerial parts.

\section{Acknowledgement}

The authors are thankful to Principal A.N. College, Patna- 800013 for providing necessary library and laboratory facilities.

\section{References}

Babu, C.R., 1977. Herbaceous Flora of Dehra Dun. CSIR New Delhi.

Bailey, L.H., 1949. Manuals of Cultivated Plant.

Chopra, R.N., S.I. Nayar and J.C. Chopra, 1956. Glossary of Indian Medicinal Plants. CSIR. New Delhi.

Haines, H.H., $1921-25$. The Botany of Bihar and Orissa. 6 Vols.

Jain, S.K., 1968. Medicinal Plants. National Book Trust, New Delhi.

Kumar, H. D., Cooper, Edwin L.; Yamaguchi, Nobuo, eds. 2004. Management of Nutritional and Health Needs of Malnourished and Vegetarian People in India. Advances in Experimental Medicine and Biology. Springer US. 
pp. 311-321. ISBN 978-1-4419-3441-3

Olson, Mark E 2010. Moringaceae Martinov; Drumstick Tree Family; In: Flora of North America, North of Mexico, Volume 7: Magnoliophyta: Dilleniidae, Part 2. Oxford University Press. p. 168. ISBN 0195318226.

Pandit, V., 1996. Flora of Dinapore. Ph.D. Thesis.

Ray, Piyush, 2009. Ethno - botanical studies of some medicinal plants of Buxar District. Ph.D.Thesis.

Ronald, Pamela and McWilliams, James 2010. Genetically Engineered
Distortions The New York Times, 1 October 2012

Rossetto, M.R., Oliveira do Nascimento JR, Purgatto E, Fabi JP, Lajolo FM, Cordenunsi BR 2008. "Benzylglucosinolate, benzylisothiocyanate, and myrosinase activity in papaya fruit during development and ripening". $J$ Agric Food Chem. 56 (20):95929..

Singh, V., Pandey P.C. and Jain D.K. 2005. Economic Botony Rastogi publications meeruth.

\section{How to cite this article:}

Nishu, Babaloo Kumar and Chandrawati Jee. 2017. Ethano-Botanical and Medicinal Uses of Moringa Spp. and Carica Spp. Int.J.Curr.Microbiol.App.Sci. 6(10): 3290-3294. doi: https://doi.org/10.20546/ijcmas.2017.610.385 